\title{
FROM THEOCRACY TO DEMOCRACY? TOWARDS SECULARISATION AND INDIVIDUALISATION IN THE POLICY OF THE MUSLIM BROTHERHOOD IN JORDAN
}

\author{
Anne Sofie Roald \\ Chr. Michelsen InStitute, Bergen, NORWAY ${ }^{1}$
}

\begin{abstract}
There is a common assumption that 'Islam' has an inherent opposition between the sacred and the secular which obstructs the secularisation process witnessed in western societies. This study argues that Weber's notion of Protestant religion as a driving force in the rationalisation of society might be an indicator of how political Islam in itself in the end might lead to a differentiation between the religious and the secular sphere; an individualisation and a secularisation of the Islamic message and thereby to a privatisation of religion. The political experience of the Muslim Brotherhood in Jordan is analysed in view of western theories of secularisation, particularly Steve Bruce's study on secularisation in British society. As Islamists work within the democratic system, there seems to be a transformation from being a radical organisation towards becoming 'just another comfortable denomination', as expressed in Bruce's claim that 'the sectarian project' is 'largely self-defeating'.
\end{abstract}

\section{Introduction}

The pervasive and generally accepted idea of increasing secularisation in modern society appears to have been corrected in the 1980s. The sociologist José Casanova wrote in 1994 that in the 1980s 'religion went public in a dual sense', explaining this as religion entering 'the public sphere' and thereby being exposed to 'publicity'. ${ }^{2} \mathrm{He}$ names this phenomenon 'deprivatisation' of religion, claiming that 'religious traditions throughout the world are refusing to accept the marginal and privatized role which theories of modernity as well as theories of secularization had reserved for them. ${ }^{3}$ According to Casanova, this new awareness of relig-

\footnotetext{
${ }^{1}$ This research project, Moderation of Islamist Movements, is funded by the Norwegian Research Council.

2 José Casanova, Public Religions in the Modern World (Chicago and London: University of Chicago Press, 1994), 3.

${ }^{3}$ Ibid., 5.
} 
ion in the public sphere was manifested in four simultaneous developments in various parts of the world: the Islamic revolution in Iran (1979), the popular Solidarity movement in Poland (1980), the role of Catholicism in conflict in Latin America (1970s onward), and increased public re-emergence of Protestant fundamentalism in the USA. ${ }^{4}$

The question that arises, however, is whether we are entering into some 'post-secular' age as Habermas has suggested, or whether we are witnessing the last convulsion of religion in the power game between religious and secular institutions? ${ }^{5}$ Whereas Casanova sees a revival of public religion, that is, a deprivatisation of religion, the sociologist Steve Bruce, on the other hand, referring for instance to how churches that accept democratic principles and the paradigm of individual rights have regained a public role, regards the success of these churches to be $a$ result of their secularisation. Thus, Bruce states that, 'religious interest groups have been effective in the public arena only when they have presented their case in secular terms,' and goes on to claim that, 'religious interest groups can be effective in civil society only when they accept the privatisation of their distinctive religious beliefs and move on to secular ground.' ${ }^{6}$ Casanova's concept of deprivatisation of religion might thus be a deprivatisation of a 'politicised' and therefore a 'secularised' religion.

There might be a tendency, similar to that in many western societies, towards differentiation of religion and religious institutions from the secular sphere and the subsequent privatisation of religion. That is to say, the marginalisation of religion to a privatised sphere, when Islamist parties enter the political arena. Islamic political activism is arguably an effect of modernisation processes, but it might also instigate further modernisation and secularisation processes in society. This present study will examine the case of the Muslim Brotherhood in Jordan, investigating how the organisation's policy has been secularised as a result of its political experiences. The discussion builds on empirical material gathered in Jordan during field trips in 1991, 1992, 1995 and in 2007, as well as on interviews with Islamists of various orientations, Islamic- and secular-oriented politicians, and leading members of the Muslim Brotherhood.

\footnotetext{
${ }^{4}$ Ibid., 3.

5 Jürgen Habermas, Religion and Rationality: Essays on Reason, God, and Modernity (Oxford: Polity, 2002).

${ }^{6}$ Steve Bruce, God is Dead: Secularization in the West (Oxford: Blackwell, 2002), 21.
} 
In the aftermath of political Islamist popularity in many countries with majority Muslim populations, a notion has emerged that such societies are 'religious' in contrast to secularised western countries. Furthermore, one often meets with the argument that the nature of the religion of Islam makes its followers oppose secularisation, and that 'Islam' embodies some inherent opposition between the sacred and the secular since it started both as a political movement and a charismatic religious community. Moreover, another pervasive assumption is that the believers' claim that the Qur ${ }^{0} \bar{n}$ is God's literal word further obstructs secularisation processes. However, in contrast to these assumptions, I will argue that Weber's notion of Protestant religion as a driving force in the rationalisation of society can be taken as an indicator of how political Islam in itself might lead to a differentiation between the religious and the secular sphere - an individualisation and a secularisation of the Islamic message - and thereby to a privatisation of religion.

\section{Secularisation theories}

Casanova discusses secularisation theses in terms of three different propositions. One proposition is that secularisation is understood as 'differentiation of the secular spheres from religious institutions and norms'.$^{7}$ Another proposition represents secularisation as 'marginalisation of religion to a privatised sphere'. A third proposition makes secularisation a 'decline of religious belief and practices'. ${ }^{8}$ Not all of the classical secularisation theorists, according to Casanova, have distinguished between these three phenomena; rather they have used the term 'secularisation' as a general concept to cover all three or only one or two of these propositions. ${ }^{9}$

\section{Differentiation}

Secularisation theories from the 1960s were, to a certain extent, based on an Enlightenment critique of religion, with the assumption that processes of modernisation will eradicate religion and religious expressions. The Weberian 'rationality' doctrine, which in Meredith McGuire's words is explained as 'the process by which certain areas of social life are organised according to the criteria of means-end (or functional) rationality' was a further inspiration. ${ }^{10}$ Peter Berger, one of the secularisation theo-

\footnotetext{
${ }^{7}$ Casanova, Public Religions, 211.

${ }^{8}$ Ibid.

${ }^{9}$ Ibid.

${ }^{10}$ Meredith McGuire, Religion: The Social Context (Belmont, California: Wadsworth Pub. Co., 1987), 232.
} 
rists following Weber, saw the process of rationality as a "process by which sectors of society and culture are removed from the domination of religious institutions and symbols'. ${ }^{11}$ In his definition of secularisation he points to an on-going privatisation of religion rather than what some Enlightenment critiques of religion promoted: a total eradication of religion.

\section{Marginalisation}

Berger went further in his claim concerning how the nature of the religious tradition in itself might trigger a secularisation process. Following Weber's concept of 'disenchantment of the world', Berger states that Protestantism liberated itself from the traditional religious expressions of the sacred, such as mysteries, miracles and magi. In contrast to Catholicism, in which one could live in a world where the 'holy' was never far away, in Protestantism conceptions of saints, angels, holy objects, sacraments and so on disappeared, ousted into a sacred world far away from the reach of believers. ${ }^{12}$ Thomas Luckmann, another of the secularisation theorists, had an approach to religion and religious manifestation in the modern world similar to that of Berger. With his concept of 'the invisible religion', he too pointed to an increased differentiation between the secular and the religious spheres, resulting in a marginalisation of religion in society. ${ }^{13}$ It seems that Berger and Luckmann in the 1960s used the term 'secularisation' to denote what we today might regard as the 'privatisation of religion', that is, including both the phenomenon of differentiation of the religious and the secular spheres and a following marginalisation of religion in the public sphere, rather than secularisation in the Enlightenment sense, that religion will disappear altogether. ${ }^{14}$ This becomes obvious in their definition of secularisation as 'the progressive autonomization of societal sectors from the domination of religious

11 Peter L. Berger, The Sacred Canopy: Elements of a Sociological Theory of Religion (New York: Doubleday, 1967), 107.

12 Ibid., 111.

13 Thomas Luckmann, The Invisible Religion: The Problem of Religion in Modern Society (New York: Macmillan, 1967).

${ }^{14}$ See Casanova, Public Religions, 19, where he states that the secularization thesis in the 1960s was a break with the 'ideological origins in the Enlightenment critique of religion and [an attempt] to distinguish the theory of secularization, as a theory of the modern autonomous differentiation of the secular and the religious spheres, from the thesis that the end result of the process of modern differentiation would be the progressive erosion, decline, and eventual disappearance of religion.' 
meaning and institutions'. ${ }^{15}$

Decline

Some sociologists, as for instance Steve Bruce, have in recent years, (re)turned to an Enlightenment understanding of secularisation. Whereas Casanova doubts that differentiation between the secular and the religious sphere necessarily leads to impiety, Bruce claims that there is a strong link between the social importance of religion, the number of people who takes it seriously, and how seriously anyone takes it. ${ }^{16} \mathrm{Al}-$ though there might be many religious persons in a secularised country, he states, evidence from Britain at least indicates that a decline in the social significance of religion has led to a decline in the numbers of religious people and a decrease in how religious these people are. ${ }^{17}$ Bruce is careful, however, not to make this explanation a universal claim, stating that it is necessary to study different societies in order to find their specific characterisations.

Islamism: Deprivatisation of religion or secularisation?

The political experience of the Islamists in Jordan is interesting in order to understand the phenomenon of Islam as a 'public religion'. Most of my informants classify Jordan as a conservative (muhăfiz) society, claiming that most people living in Jordan promote family values, that is, collective norms. They also tend to dissociate themselves from the sexual freedom of 'the West', and endorse their religious traditions, whether they are Muslims or Christians. ${ }^{18}$ The royal family's claim to descent from the Prophet Muhammad exemplifies the impact of religion in the country. King Husayn, who ruled from 1953 until his death in 1999, managed to strike a balance between the secular state system and Islamic rules and injunctions. ${ }^{19}$ The result is that the Islamist movement in Jordan has had a unique possibility to grow and to influence the society in general. However, as will be argued below, the general society and

\footnotetext{
15 Peter L. Berger and Thomas Luckmann, The Social Construction of Reality (New York: Doubleday, 1966), 74.

16 Bruce, God is Dead, 3.

17 Ibid.

18 Wiktorowicz confirms this image of Jordan as 'a conservative, tribal society'. Quintan Wiktorowicz, The Management of Islamic Activism: Salafis, the Muslim Brotherhood, and State Power in Jordan, (Albany, New York: State University of New York Press, 2001), 41.

${ }^{19}$ Nahman Tal, Radical Islam in Egypt and Jordan, (Brighton; Portland: Sussex Academic Press/Jaffee Center for Strategic Studies, 2005), 167-71.
} 
secular ideas have also influenced Islamists as they have started to participate in political life.

\section{The Muslim Brotherhood in Jordan}

The Egyptian schoolteacher Hasan al-Bannā (1906-49) established the Islamist organisation, the Muslim Brotherhood in 1928, and in 1945 the Jordanian branch was set up. ${ }^{20}$ The Muslim Brotherhood is a cadreorganisation; there are strict membership rules and regulations. The supreme leadership is situated in Egypt, and although the leading members of the organisation in Jordan expressed that all regional branches are free to follow their own policy according to the specific needs in their region, centralised directives, coming from above, play a fundamental role for the various branches' official policy. One example is how political parties, either within or partly independent from the organisation emerged simultaneously in many of the organisation's branches. ${ }^{21}$ Another example is how, in Jordan, women started to participate in politics immediately after the central directive on women's role in politics was launched by the Muslim Brotherhood's Egyptian headquarter. ${ }^{22}$

\section{Ideology}

The Muslim Brotherhood's ideology is developed from the idea of Islam as a comprehensive system (nizāam shämil). ${ }^{23}$ The organisation's goal was until recently to create an Islamic state through gradual awareness and education (tarbiya) of the masses. The idea was and is still today that the 'call to Islam' $\left(d a^{c} w a\right)$ together with the non-formal and formal education of the masses (tarbiya and $t a^{c} l i m$ ) will create a situation where the masses will demand an Islamic state. That is, through enlightenment and education people will understand that Islam is the 'truth'.

$20{ }^{\mathrm{c}}$ Awnī Jadwa ${ }^{\mathrm{c}}$ al- ${ }^{\mathrm{c}} \mathrm{Ubayd} \overline{1}$, Jamā ${ }^{c}$ at al-ikhwān al-muslimīn fì l-Urdun waFilasțin, 1945-1970 (Amman: n.p., 1991), p. 34. For more information on The Muslim Brotherhood in Jordan, see Anne Sofie Roald, Tarbiya: Education and Politics in Islamic Movements in Jordan and Malaysia (Stockholm: Almquist \& Wiksell International, 1994), 97-213.

${ }^{21}$ For a central directive on the establishing of political parties, see 'The Muslim Brotherhood's Statement on Shura in Islam and the Multi-Party System in an Islamic Society', Encounters: Journal of Inter-Cultural Perspectives 1/2 (1995): 100-103.

22 For a central directive on women's political participation, see Anne Sofie Roald, Women in Islam: The Western Experience (London: Routledge, 2001), 195-97.

23 Roald, Tarbiya, 180. 
The search for knowledge is central in the organisation, and the study of Islamic texts is in itself an important part of the educational process. The members have regular text studies and are expected to transfer their knowledge to society in general. ${ }^{24}$ According to the Muslim Brotherhood, increased knowledge will result in an understanding of the message of Islam as 'logical' (mantiqu $\bar{l}$ ) and 'rational' ('aqlī). The logic is, according to the organisation, inherent in the Qur ${ }^{\circ} \bar{a}$ nic call for understanding the existence of God through the creation.

The 'rational' understanding of Islamic texts is linked to the organisation's view on natural science and the fact that many of the members and sympathisers are educated in natural sciences, particularly within medicine and technical subjects. In my interviews with members and sympathisers of the Muslim Brotherhood, many claimed that in contrast to the Old and the New Testaments, scientific discoveries do not contradict the Qur ${ }^{\circ} \bar{n}$, rather they confirm its content. These Islamists' view on technical progress as 'good' and beneficial is reflected in their notion of utilising the 'good' from the West and leaving the 'bad'. This notion can be described as Islamists accepting 'modernity' in terms of technical progress, whereas they refute 'modernity' in terms of the overarching content of ideas, such as secularisation and individualisation.

\section{Islamism and deprivatisation of religion}

Bruce sees exceptions to the trend of an increasingly privatised religion. He states that when religion 'finds work to do other than relating individuals to the supernatural, ${ }^{25}$ there might be countertrends, namely 'cultural defence' and 'cultural transition'. ${ }^{26} \mathrm{He}$ also notes that religion continues to be a powerful social force if religion is implicated in group identity. ${ }^{27}$

Where culture, identity and sense of worth are challenged by a source promoting either an alien religion or rampant secularism and that source is negatively valued, secularisation will be inhibited. Religion often provides resources for the defence of a national, local, ethnic or status-group culture. ${ }^{28}$

He refers at the example of the Catholic Church, which in many countries tries to remain in control by having its own school system and

\footnotetext{
24 Ibid., 118-20.

25 Bruce, God is Dead, 30.

26 Ibid.

27 Ibid., 31.

28 Ibid.
} 
creating its own organisations, such as trade unions and professional associations parallel to similar secular organisations. ${ }^{29}$ Transferred to the Islamist sphere it is possible to see the revival of the Islamic message from the 1960s and the 1970s and onwards as part of Bruce's pattern of 'cultural defence'. The Arab countries' Six-Day War against Israel in 1967, which ended in a stinging defeat for the Arab allies, has by many been regarded as a turning point in Islamic awareness. ${ }^{30}$ The Six-Day War is by Arabs in general called 'the Disaster' (al-nakba), and the defeat led to the same question that preoccupied the nineteenth-century's intellectual salafiyya-movement: how could Muslims who had previously been the rulers of the world now be in such misery? This question also led to a similar conclusion as in the nineteenth century, namely that the reason for the Muslims' problem is that they have forgotten the 'real Islam'. ${ }^{31}$

The outburst of religious enthusiasm after 1967 is also evident in other parts of the Muslim world. In Malaysia, the 1969 riot, where the Malay poor masses and the new educated elite took their frustration to the streets and to university campuses, signified a turning point in the Malay Muslim consciousness. Islam came to the forefront of Malay consciousness. Kamaruddin Muhammad Nor, one of the leading activists of the riot stated that, 'all groups have to find ways to articulate themselves, and we, the Malays, have no alternative to express ourselves other than through Islam.' ${ }^{32}$ The common notion among Islamists from this period onwards was that the Muslim world had tried all '-isms', capitalism, socialism, communism, etc., with all failing. What was left was Islamism, and the catchphrase 'Islam is the solution' emerged as a forceful slogan of the Islamic revival movement.

The development within the Muslim world from the 1967 onwards, particularly within Islamist political activism, must be seen in view of Bruce's notion of 'cultural defence' as a countertrend to the secularisation process as religion, 'finds work to do other than relating individuals to the supernatural'. ${ }^{33}$ The Islamic revolution in Iran, the political participation of Islamists in various countries in the Middle East, and the

\footnotetext{
${ }^{29}$ Ibid.

30 John Esposito, Islam: The Straight Path (Oxford; New York: Oxford University Press 1998), 160.

31 Ibid., 161.

32 Ozay Mehmet, Islamic Identity and Development: Studies of the Islamic Periphery (London: Routledge, 1990), 152.

${ }^{33}$ Bruce, God is Dead, 30.
} 
latest trend of Islamic extremism can thus be regarded as effects of such a 'cultural defence' approach. Noteworthy is the statement of Munīr Hamārnah, the head of the Communist Party in Jordan, who expressed the following:

In Jordan the problem is that the Islamists, not only the Muslim Brotherhood, but a general Islamist approach, have increased due to the confrontation with the West. This confrontation is like a clash of civilisations. Before there was no such zealot approach (tashaddud) in religious affairs as there is now. But the political situation has created an intensification of religion in Jordanian society. ${ }^{34}$

Not unlike the activity of the Catholic Church, with its establishment of parallel institutions, schools, trade unions and the like, the Islamisation process of the $1970 \mathrm{~s}, 80 \mathrm{~s}$, and $90 \mathrm{~s}$ led to the establishment of Islamic institutions all over the Muslim world, such as Islamic banks and Islamic schools, mostly run by members of the Muslim Brotherhood. Although Islamists in Egypt and Jordan did not establish new trade unions, they have actively participated in and presently control many trade unions. Thus, as with the Catholic Church, the example pointed out by Bruce, Islamists' 'cultural defence' approach has involved the creation of parallel institutions, thereby strengthening and reinforcing the anti-secularist trend in society. Moreover, the political situation, with constant political confrontation with the West, the Palestine-Israel conflict, the war in Iraq, the presence of western military forces in Afghanistan, and so on, has created a situation where 'Islam' has become the instrument of protest, as noted above by Hamārnah. The question which arises, however, is whether the 'cultural defence' impediment is blocking the process of secularisation completely or whether it only slows down the process?

The second countertrend to the secularisation process mentioned by Bruce is 'cultural transition', referring to the example of the USA. 'Americans are fond of churches,' he states, but on the other hand, 'much American religion does not seem especially religious.' ${ }^{35}$ His explanation for this apparent contradiction is that assimilation of immigrants into American society was mainly done through religious institutions, as the religious communities, 'offered a supportive group that spoke one's language, shared one's assumptions and values, but that

\footnotetext{
${ }^{34}$ Interview with Munīr Hamārnah, Head of the Communist Party, Amman, Jordan, August 22, 2007 (the author's translation from Arabic).

35 Bruce, God is Dead, 34.
} 
also had experience of, and contact within, the new social milieu. ${ }^{36} \mathrm{~A}$ similar trend can be noticed within the Muslim communities in western countries, as mosques and Islamic institutions have mushroomed in western society from the 1970s onwards. The religiosity of Muslims living as minorities in western countries has even had an impact on the Muslim world. First, the Muslim Brotherhood, as well as many other Islamist organisations, is a worldwide organisation with close contact between local branches in western countries and the mother organisation in the Middle East. The interaction, whether on a personal or on an organisational level, between the various regional branches might affect actual policy. Even the globalisation of the media, with Arabic satellite channels broadcasting all over the world with participants from the Middle East as well as from western countries, has an impact on the development within Muslim organisations and institutions in both regions.

Moreover, even in societies with Muslim majorities, the last decades have been marked by cultural transitions. Modernisation, with its industrialisation and urbanisation processes, changes traditional communities; family constellations are transformed, employment patterns and status hierarchies are disrupted, and the new urbanised, often poor, population constitute either a potentially 'dangerous mob' or they could be 'motivated to embrace the models of respectable performance offered to them, especially when they are already in the process of upward mobility and self-improvement. ${ }^{37}$ In Jordan, the respectable life is the religious life, and thus in this society, modernity in itself might trigger the way towards increased Islamism and Islamisation of society.

Alan Gilbert claims that industrialisation and urbanisation might give rise to reform and revival movements, saying that in the initial industrialisation period in Great Britain, religion became a safe haven for many in time of rapid social changes. ${ }^{38}$ In the long run, however, as noted by the Church Historian, Hugh McLeod, industrialisation diluted the position of religion in the industrialised society, owing mainly to the improvement in economic standard. ${ }^{39}$ Although Jordan, economically speaking, is still an underdeveloped country, it has a mining industry and

${ }^{36}$ Ibid.

${ }^{37}$ Ibid., 35.

38 Alan D. Gilbert, Religion and Society in Industrial England: Church, Chapel and Social Change, 1740-1914, (London; New York: Longman, 1976).

${ }^{39}$ Hugh McLeod, Secularisation in Western Europe 1848-1914 (London: St. Martin's Press, 2000), 6. 
the country is rich in phosphate and potash. Moreover, Jordan's opening up to the World Trade Organisation, and the ratification of the USJordan Free Trade Agreement and of the Euromed program, ${ }^{40}$ point towards a forthcoming industrialisation process and a more complete participation in the global economy.

Thus, although the 'cultural transition' has been an impediment to the secularisation process even in the Muslim sphere, this might be, as in western society, an impediment in the initial phase of modernisation but possibly a trigger of secularisation in a later stage of modernisation processes. And the same question arises: Is the increased religiosity a growing and long-lasting phenomenon, or is it only an impediment that slows down the process of secularisation rather than blocking it altogether?

\section{Islamism and secularisation: Rationality}

As Islam has a similar concept of a transcendent God to that of Judaism and Christianity, following Weber's and Berger's notion of rationality and secularisation, a similar development towards a differentiation between the secular sphere and the religious institutions and norms might be anticipated even in countries with a Muslim majority population. Also Weber's claim that modernisation leads to rationality has possible implications for Islamism. Weber saw the manifestation of such rationality not only in social affairs, but even as a manifestation in a state of mind. ${ }^{41}$ The 'rational mentality' is, according to him, characterised by an openminded approach to new ideas and new ways of acting in contrast to the traditional way of doing things, 'as it has always been done' ('traditional behaviour')..$^{42}$

McGuire explains this contrast between the two forms of behaviour as the traditional farmer who prepares the soil for planting in the same way it has always been done, whereas the 'modern farmer' considers new methods, 'according to rational criteria, such as relative productivity, costs versus benefits, and appreciation of land values. ${ }^{43}$ Thus rationality, according to the Weberian legacy, changes the way people think and

\footnotetext{
40 'The Hashemite Kingdom of Jordan', athttp://ec.europa.eu/external_relations/ jordan/index_en.htm [accessed 7 April, 2008].

41 Max Weber, The Theory of Social and Economic Organization (New York: Free Press, 1997); Max Weber and Max Rheinstein, Max Weber on Law in Economy and Society (Ann Arbor: University of Michigan, 1954), xxxviii.

42 McGuire, Religion, 286.

43 Ibid.
} 
the way they act. Similarly, Islamism is a break with the 'traditional' law-school Islam, where laws and regulations were built on classical scholars' analyses and deductions from the Islamic sources. The modernist Islamist claim is to return to the Qur ān and Sunna for new reinterpretations. Although this claim is made in order to return to the 'pure' understanding of the religious injunctions, the Prophet's 'real intention', the effect is somewhat different. In the process of interpretation, time, place and the interpreter's biography constitute the sociocultural background for reasoning and understanding. This makes the Islamist interpretation a 'modern' and thus a 'rational' interpretation, rather than a reflection of the traditional society's 'original' understanding of the text. ${ }^{44}$ 'Rationality' within the Islamist movement further includes an adaptation to a 'rational' understanding of the Holy Scripture: the Qur ${ }^{\circ} \bar{a}$ is to be understood within a pattern of scientific research results.

Bruce has discussed the impact of science and technology on religious traditions. He believes that although science is an important factor in orienting human beings towards the secular world rather than religion, the development of technology has an even stronger impact on religious belief. He points at how religion in the Middle Ages and in pretechnological societies in general was practical: 'Holy water cured ailments and prayers improved crop quality. ${ }^{45}$ In this sense the development of technology decreased the need for God, thus having a secularising effect by reducing religiosity in society. Bruce writes:

The gradual accumulation of scientific knowledge gave people insight into, and mastery over, an area that had once been a mystery; the need and opportunity for recourse to the religious gradually declined. Science and technology do not create atheists; they just reduce the frequency and seriousness with which people attend to religion. ${ }^{46}$

Bruce's statements have to be considered in light of Islamists' and particularly the Muslim Brotherhood's promotion of the slogan 'Modernity, but not westernisation,' which means that Muslims should adopt the

\footnotetext{
${ }^{44}$ It might of course be argued that as the Koran is regarded as a universal Holy Text, the divine 'intention' should be suitable for every time and place, and that Islamists are looking for the 'true' intention rather than the 'original' understanding. The search for intention is, however, also a modern interpretation influenced by modern values and attitudes.

45 Bruce, God is Dead, 27.

46 Ibid.
} 
'good' from the West, i.e., technology and science, and leave the 'bad', i.e., western values and ideologies. The content of this slogan can be explained by Bruce Lawrence's definition of 'modernity' as the material structures, such as for instance technology and scientific developments, and 'modernism' as the belief in the infallibility of science and human reasoning. ${ }^{47}$ In the Islamist trend the notion of 'Islamisation of knowledge' developed from the 1980s onwards. It was particularly the Islamist philosopher, Ismā $\bar{c}^{c} \bar{l}$ al-Fārūqī, one of the founders of the International Institute of Islamic Thought (IIIT) in the United States in 1981, who was the engineer behind the Islamisation process. Although the main concern of this Islamist trend of Islamisation was the Islamisation of the social sciences, ideas about the Islamisation of natural sciences and technology are also emphasised. I used to attend lectures and discussions weekly at IIIT's branch in Jordan, which was run by a member of the Muslim Brotherhood, during my visits in the 1990s.

As Bruce has noted, technology decreases the dependency on divine forces. Rationality, inevitably associated with technology, thus changes the way people think and subsequently the way they act. The question which arises is whether it is possible to remain outside the modernist paradigm in the sense of 'modernism', the belief in the infallibility of science and human reasoning and thus rationality, if 'modernity', in the sense of the technical tools which in the end might create a 'rational' attitude, is adapted? It is interesting that the Swedish scholar of Islamic Studies, Jan Hjärpe, has named this Islamist trend of the Muslim Brotherhood and particularly the Islamists within the IIIT trend, 'engineer-Islam', indicating a particular 'rational' and 'technical' way of understanding Islam.

\section{Relativisation}

Casanova regards the Protestant Reformation in itself as a secularising force in its questioning of papal authority and in its destruction of the unity of western Christendom. ${ }^{48}$ Similarly, the consequence of the Islamic reform movement of the nineteenth and twentieth centuries was not a purified and strengthened institution, rather it instigated splits and the establishment of competing movements. The division into fractions started in the early history of the reform movement, and later, in the 1980s and 1990s, Islamist movements with different ideological stands

\footnotetext{
${ }^{47}$ Bruce Lawrence, Defenders of God. The Fundamentalist Revolt against the Modern Age (San Francisco: Harper and Row, 1989), 27.

${ }^{48}$ Casanova, Public Religions, 21-22.
} 
mushroomed all over the world. It is however in the wake of the September 11th attacks in 2001 that the number of Islamist movements has reached its peak, with extremist Islamist movements splitting into various obscure fractions.

Bruce believes that the element of 'relativism' has been neglected in the discussion of secularisation. He notes that the social-psychological consequence of increased diversity is that it calls into question the certainty that believers can accord their religion. ${ }^{49}$ He states:

When the oracle speaks with a single clear voice, it is easy to believe it is the voice of God. When it speaks with twenty different voices, it is tempting to look behind the screen. As Berger puts it, . . . the position of the modern believer is quite unlike that of the Christians of the Middle Ages in that, while we may still believe, we cannot avoid the knowledge that many people (including many people like us) believe differently. ${ }^{50}$

\section{Bruce continues:}

The secularisation case is that diversity weakens religious commitments by removing the social support for any one religion and by encouraging people to confine their religious beliefs to specific compartments, ... and to remove the specific and contested elements from their beliefs. ${ }^{51}$

Per-Johan Ödman has examined how, during the eighteenth and nineteenth centuries, Swedish religious revival movements led to relativisation and an individualisation of the religious message, which in turn created the intellectual ground for the secularisation of Swedish society. ${ }^{52} \mathrm{He}$ also points at how the liberal reform-oriented clergy within the state church played a decisive role in the development of Swedish individualism. He claims that they laid the foundation for the individualisation of religion which has become an important characteristic of Swedish religiosity. These priests trained the communality to read the catechism without the agency of the clergy, an important factor in the incipient process of secularisation. But Ödman emphasises that the reformers were not aware of the consequences of their literate policy. ${ }^{53}$ The effect of both the increasing literacy among common people and the

49 Bruce, God is Dead, 17, quoting Berger 1980.

50 Ibid., 18.

51 Ibid., 22.

52 Per-Johan Ödman, Kontrasternas spel: En svensk mentalitets- och pedagogikhistoria (Stockholm: Norstedt, 1995).

53 Ibid., 314. 
revival movements' questioning of the hierarchical role of the state church was the rise of a new and modern form of Swedish Christianity. ${ }^{54}$ Through the agency of common people in the process of interpretation, the content of the faith was transformed from being based on the religious authorities' infallibility to a reflecting individualised faith. ${ }^{55}$

A similar development of disruption of the Islamic unified message can be seen in the Islamist context. Firstly, the notion of 'the natural religion' (al-din al-fitra) has become a central concept in the ideology of the Muslim Brotherhood, building on 'rational' faith arguments. The term fitra ('nature' or 'natural disposition') is taken from a hadith saying: 'Every child is born in conformity with the natural disposition (alfitra); it is the parents who turn children into Jews or Christians. ...'56 The Islamic idea of 'natural religion' is that the spiritual link between God and the human being weakens or breaks off if the human being's environment does not reflect the 'true' representation of Islam. Through Islamic informal and formal education the spiritual bond can be restored as human beings comprehend the 'rational' in the Islamic message. The concept reflects the Enlightenment notion of 'the natural religion', particularly in the ideology of Thomas Paine. ${ }^{57}$ The Muslim Brotherhood's members often refer to the Qur ānic verse, 27:60, in order to give evidence of the 'logical' and the 'rational' approach of Islam:

Nay - who is it that has created the heavens and the earth, and sends down for you [life-giving] water from the skies? For it is by this means that We cause gardens of shining beauty to grow - [whereas] it is not in your power to cause [even one single of] its trees to grow! Could there be any divine power besides God? Nay, they [who think so] are people who swerve [from the path of reason]. ${ }^{58}$

Another passage referred to by members and sympathizers of the

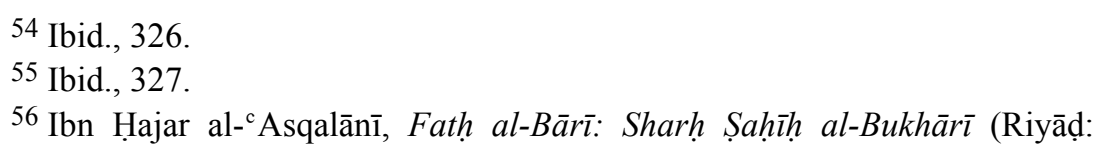
Maktabat Dār al-Salām, 2000), 11: 502; hadīth no. 6369 [6599]. Author's translation in agreement with editors.

57 See Thomas Paine, The Age of Reason, (New York, 2007 [1807]).

58 Qur $^{\top} \bar{a}$ 27:60. Even the Qur ${ }^{\circ} \bar{a}$ ic verses 27:61 and 35:27 are referred to in the lectures. The translation and interpretation of the quoted verse is that of the Jewish Polish convert to Islam Leopold Weiss who took the name Muhammad Asad as he converted to Islam. See Muhammad Asad, The Message of the Qur'an (Gibraltar, 1980; or http://www.geocities.com/masad02/021). 
Muslim Brotherhood consist of the first revealed verses of the Qur'ān, which say: 'Read in the name of thy Sustainer, who has created - created man out of a germ-cell.' 59 Heard in lectures, Friday sermons, and often to be found in Islamist literature, this Qur ${ }^{\top}$ annic passage, starting with the word, 'read' or 'recite' $\left(\right.$ iqra $\left.^{\circ}\right)$, is used as evidence that the duty of the human being is to search for knowledge $\left({ }^{c} \mathrm{ilm}\right)$. Islamists thus present, like the Scandinavian priesthood in the eighteenth and nineteenth centuries, an instrument for common people to liberate themselves from traditional and hegemonic religious patterns of interpretation, setting the ground for the creation of a reflecting and individualised faith.

It is significant to note that the Norwegian historian Bjørn Olav Utvik has pointed to a certain resemblance between the Norwegian religious revival movement in the eighteenth and nineteenth centuries, a movement which resembles the Swedish one, and the Muslim Brotherhood in contemporary Egypt. He discusses mainly the religious revival movements' role in the economic and to a certain extent political development of the two countries, and does not touch upon these movements' impact on the general individualisation and secularisation processes. He claims, however, that in the aftermath of the rise of the revival movement the thought of religion as differentiated from loyalty to the king and to family emerged. Rather, he claims, personal piety was emphasised. ${ }^{60}$ This individualisation process even encouraged political engagement, he states, and in contemporary Egypt, the call of the Muslim Brotherhood is mainly to promote individual responsibility. This call is, in Utvik's view, a contingent appeal for the freedom of the individual with its advancing of literacy and political consciousness and its promotion of economic attitudes beneficial for Egyptian development. ${ }^{61}$

Establishment or non-establishment?

Casanova claims that the main reason why American Protestantism has managed to escape the secularisation trend, the trademark of its European counterpart, is that America never had an absolute state and a state church. ${ }^{62} \mathrm{He}$ further believes that the non-established European churches and sects have been able to avoid the secularisation trend. He thus sees

\footnotetext{
${ }^{59}$ Qur`ān 96:1-2, Asad's translation.

${ }^{60}$ Björn Olav Utvik, 'Religious Revivalism in Eighteenth-Century Norway and Twentieth-Century Egypt: A Critique of Fundamentalism Studies', Islam and Christian-Muslim Relations 17/2 (2006): 143-57; 149.

${ }^{61}$ Ibid., 150.

${ }^{62}$ Casanova, Public Religions, 29.
} 
the 'presence or absence of establishment' as crucial, saying that 'it was the very attempt to preserve and prolong Christendom in every nationstate and thus to resist modern functional differentiation that nearly destroyed the churches in Europe.' 63 The question which arises is whether the preservation and prolonging of for instance Shari ${ }^{c} a$ in family matters in many countries with Muslim majorities will hasten or impede the secularisation process. In view of Casanova's observation on the difference between Europe and the United States in terms of established and non-established religion, it could perhaps be posssible that the insistence on the implementation of $\operatorname{Shari}^{c} a$ in Muslim society might actually speed up the secularisation trend.

Ziba Mir-Hosseini holds that historically speaking the basis of the Shar $\bar{i}^{c} a$ was more ethical than legal. ${ }^{64}$ She claims that there are two reasons why " $[b]$ oth the process of codification and the concept of a unified legal system, which has the state as an enforcing authority behind it, are alien to the $\operatorname{Shari}^{c} a .{ }^{\prime} 65$ The first reason is that $\operatorname{Sharī}^{c} a$ in its classical form, 'allowed fluidity in the demarcation between the moral and the legal aspects of human conduct,' as it was open to individuals' need and specific circumstances. ${ }^{66}$ Secondly, she points at how Sharī $a$, even in the practice of family legislation, never was a formal legal code enforced by the state, rather it was binding upon those Muslims 'who felt themselves in a direct relationship with God, regardless of territory and state. ${ }^{67}$ The Shari ${ }^{c} a$ 's aim, she claims, referring to the classical work on Islamic law by Joseph Schacht, 'was to set concrete and material standards, and not to impose formal rules on the play of contending interests, which is the aim of secular law'. ${ }^{68}$

At present, the personal status law in most countries with a Muslim majority is based on $\operatorname{Sharī}^{c} a$ rulings. During my fieldtrip in Sudan in February 2007, I discovered that even the leftist political parties regarded Shar $\bar{l}^{c} a$ rulings in personal status law as the only alternative. ${ }^{69}$ In Jordan,

63 Ibid.

${ }^{64}$ Ziba Mir-Hosseini, Marriage on Trial: A Study of Islamic Family Law (London, I. B. Tauris \& Co., 2000), 11.

65 Ibid.

66 Ibid.

67 Ibid.

68 Ibid. See also Joseph Schacht, An Introduction to Islamic Law (Oxford: Clarendon Press, 1964), 5.

${ }^{69}$ Liv Tönnessen and Anne Sofie Roald, Discrimination in the Name of Religious Freedom: The Rights of Women and Non-Muslims after the Com- 
however, some of the representatives of the leftist parties expressed that they wanted a change of the family law towards an approach more grounded in individual rights. However, they believed that the changes have to be introduced gradually, mainly due to the infected situation between the 'East' and the 'West'. 'Abla Abū ' Ulba, head of the political branch of the Jordanian Popular Democratic Party in Jordan put it this way:

Arab women need to get equality with men, but we have to take care of what our situation looks like; our Arab situation. The change has to come little by little. We have to take care of what our reality looks like in order for people to understand that the changes come from us, the Arabs, and not from the West. ${ }^{70}$

There is today a massive protest against $\operatorname{Shari}^{c} a$ family law, from feminist forces within Muslim society, Muslim feminists living in western countries, and from the international community. Countries with Muslim majorities are under pressure from the United Nations to sign and ratify the CEDAW (Convention on the Elimination of All Forms of Discrimination against Women). Although some of these countries have signed the convention, most countries have restrictions on some important points, such as equal right to divorce for both men and women and the right for both men and women to marry the person of their own choice.

The present codified $\operatorname{Shari}^{c} a$ family law in the Muslim world reinforces collectivist and patriarchal social structures. It is however important to be aware of that these rulings are not necessarily the only alternative of 'Islamic' family legislation. The recent reinterpretation within Islamic legislation in general, suggests the possibility of various understandings of the Islamic texts. The pluralism within Islamic legislation, even in history, with different law-schools and legal traditions, shows further that it is hard to put the label 'absolute Islamic' on any particular legal rule or injunction. The resistance to recent $\operatorname{Shari}^{c} a$ legislation in the Muslim World is therefore not automatically antireligious, rather the criticism is directed towards certain legal practices and behaviours. However, as these legal practices and behaviours are understood as being 'Islamic', even by many opponents, the resistance

prehensive Peace Agreement in Sudan, Chr. Michelsen Institute's Report to Norwegian Foreign Ministry (Bergen, 2007).

${ }^{70}$ Interview with ${ }^{\mathrm{c}} \mathrm{Abla} \mathrm{Abu}{ }^{\mathrm{c}} \mathrm{Ulba}$, head of the political branch of the Jordanian Popular Democratic Party (hizb al-shach al-dimuqrāț al-urdunnī), Amman, Jordan, August 22, 2007 (the author's translation from Arabic). 
comes to involve criticism against Islam and not only against cultural phenomena. The establishment of Islamic law as a tool for the state as well as the resistance towards modern legislation within the era of family law might thus, as earlier in Europe, be a trigger for the secularisation process rather than an instrument for reinforcing and prolonging religion's prevailing role in society.

\section{Towards secularisation?}

The Muslim Brotherhood in Jordan might on the one hand be accused of contributing to weakening and thus relativising the dominant religious tradition, as discussed above. However, it is just as important to look at how the Muslim Brotherhood in Jordan has gone through the transformation from being a radical organisation towards becoming just another comfortable denomination, in Bruce's terms of 'the sectarian project' being 'largely self-defeating'. ${ }^{71}$ For Bruce, a religious sect or radical organisation 'hastens secularisation by weakening the dominant religious tradition and increasing the extent of diversity with all [its] consequences. ${ }^{72}$ By looking at three important political concepts, shūrā (consultation), al-dawla al-islāmiyya (the Islamic state), and qiyādat almar $a$ (female [political participation and] leadership), and investigating their development during the period from the early 1990s until 2007, this study will show that there are indications that the policy of the Jordanian branch of the Muslim Brotherhood has become more secularised after the organization's participation in official politics. ${ }^{73}$

\section{Shūrā or democracy?}

The first concept, shürā, changed in the early phase of the political experience of the Muslim Brotherhood. During my visits to Jordan in 1991 and 1992, many of the 'old guard', who had been in the top leadership from the 1970s onwards and were then members of parliament and some of them even ministers, such as Muhammad Abū Fāris, Yūsuf al- ${ }^{\mathrm{c}} \mathrm{Azụm}$, and Isḥāq Farḥān, stated that they rejected 'democracy' in the western understanding of the word. They explained that western democracy involves pluralism of political parties, and is thus 'un-

\footnotetext{
${ }^{71}$ Bruce, God is Dead, 24.

72 Ibid.

${ }^{73}$ As the leadership of the Muslim Brotherhood is centralised, the Egyptian branch being the head of the organisation, there is a similar development in the Muslim Brotherhood's organisation in general. However, this particular study is built on material gathered in Jordan from the early 1990s to 2007, and it thus focuses on the Jordanian branch of the organisation.
} 
Islamic'. ${ }^{74}$ The Qur'ānic term shūrā, they claimed, is the 'Islamic democracy', as it involves consultation among leading figures in society.

Also in the early 1990s many of the Islamists I interviewed took a stand against political parties. As the Jordanian authorities legalised political parties in 1992, members of the Muslim Brotherhood established the Islamic Action Front (IAF), which at the present time is part of the Muslim Brotherhood's organisation. This shows that the Muslim Brotherhood is pragmatic in approach; political participation leads to needs which must and can be met in spite of ideology. The notion of a return to the Koran and Sunna is the tool used by members to include modern and 'rational' thought and behaviour into the 'eternal' Islamic message. Notably in the context of secularisation, the concept of the return to the Koran and Sunna also leads to a relativisation of the Islamic message, as it includes alternative interpretations of the that message.

\section{Islamic or civil state?}

The second concept is that of the 'Islamic state' (al-dawla al-islämiyya). The notion of an Islamic state has been prominent in the ideology of the Muslim Brotherhood from its beginning. In my visits to Jordan in the 1990s, this main aim of the Muslim Brotherhood's policy was recurrently stated. However, in my interviews with leaders of the Muslim Brotherhood in Jordan in 2007, both the head of the Muslim Brotherhood, Sālim al-Falāhāt, and the General Secretary of the IAF, Zakī BanīIrshayd, discussed the aim of the Muslim Brotherhood in terms of the formation of a 'civil state'. Al-Falāhāat explicitly expressed that 'we, the Muslim Brotherhood believe in and demand a civil (madanī), and not a religious (dini $\bar{l})$ state. ${ }^{\prime 75}$ The idea behind this change is, according to alFalāhāt, that when people have the possibility to choose they will in any case choose Islam. This thought reflects Hasan al-Bannā's idea that society becomes Islamic through tarbiya (education/upbringing). However, al-Falāhât also expressed that as Jordan is a plural society with various religious directions, every individual should have the right to choose his/her religion. He exclaimed that 'we believe in the freedom of religion and thus in every citizen's rights; we do not want to force Islam

\footnotetext{
74 Interviews with Hammān Sayyid in Amman, Jordan, September 1991, with Yūsuf al- ${ }^{\mathrm{c}}$ Aẓm in Amman, Jordan, September 1991, with Isḥāq al-Farḥān in Amman, Jordan, September 1991, and with Muḥammad Abū Fāris, Amman, Jordan, July 1992.

75 Interview with Sālim al-Falāḥāt, Amman, Jordan, August 14, 2007 (the author's translation from Arabic).
} 
on anyone. ${ }^{76}$

Banī-Irshayd also described the IAF as a civil (madanī) political party with an Islamic direction, stating:

We believe in differentiation of power and balance between various centres of power. We believe in the principle that a democratically elected government will take the right decisions and that these decisions will be for the best (mașlaha) of the people and the nation. We believe in this because it [mașlaha] is the basis of Islam and $\operatorname{Sharī}^{c} a .^{77}$

According to al-Falāhāt, the demand for a 'civil state' is a more 'correct' Islamic strategy than is the 'Islamic state'. He explained this in terms of the tolerance towards Jews and Christians in early Islamic history and how Muslims and non-Muslims lived side by side and together built up the new Islamic civilisation. These references to freedom of religion and minority rights are probably a consequence of the recent international human rights discourse. Al-Falāhāt's tolerance is in contrast to the absolute 'dictatorship of the majority' implicitly promoted by the Muslim Brotherhood's members during my earlier visits to Jordan in the 1990s. The notion of the 'civil state' and the fact that the IAF has leading Christian members might even be a result of Muslim migration, as many Muslims now live in western countries where they demand their rights as religious minorities. The Muslim Brotherhood is a worldwide organisation with many local branches and prominent members within these minority communities. Thus, the discourse in western secularised countries on pluralism and minority rights may have had an impact on the policy of the Muslim Brotherhood in the Middle East.

Female political participation and leadership: qiyādat al-mar ${ }^{\circ} \mathrm{a}$ The view of female political participation has gone through considerable changes from the early 1990s until the present day. At the time of the inauguration of the IAF, Islamist women were not admitted to participate. In 1994, the central office of the Muslim Brotherhood in Egypt issued a report on female political participation. ${ }^{78}$ Women can, according to this directive, participate in politics as long as they do not have the highest leadership (al-qiyāda al- $\left.{ }^{c} u z m \bar{a}\right)$. This view is based on the hadith

\footnotetext{
${ }^{76}$ Ibid.

77 Interview with Zakī Ban̄i-Irshayd, Amman, Jordan, August 12, 2007 (the author's translation from Arabic).

78 The report is called The Role of Muslim Women in Islamic Society according to the Muslim Brotherhood. See also Roald, Women in Islam, 195-97.
} 
which states that, "No people will succeed that hands over its affairs to a woman,' 79 a hadìth that has been extensively discussed both by the Moroccan feminist Fatima Mernissi ${ }^{80}$ and by the Egyptian Islamist Muhammad al-Ghazālī (d. 1996). ${ }^{81}$

Women obtained immediate access to membership in the IAF after the directive from the central headquarters, and in 2007 many women were members of the party. It is interesting to note that Hayāt al-Masīmī, the leader of the female branch in the IAF, stated that there still is opposition to female political participation, even among women within the Muslim Brotherhood. In my interviews with members of the Muslim Brotherhood in 2007, all the leading men and most of the leading women expressed the opinion that women can have any political position except prime minister, president, and caliph. Al- Masīmī, however, who was a member of parliament at the time of the interview, ${ }^{82}$ stated explicitly that a woman can have any position except caliph. In this issue she goes against the official line of the Muslim Brotherhood, and it possibly her own political experience which informs her conclusions about women as leaders. The position of caliph is, as we know, hypothetical.

Al- Masīmì's insistence on gender equality indicates how the secular perspective of individual rights comes to the forefront when women become actors in wider society. Although Jordan in general and the Muslim Brotherhood in particular have a basically conservative outlook with respect to traditional gender notions and roles, the increased globalised message of individual rights and gender equality may penetrate social ideologies because of the actual political experience of women.

\section{Reflections}

The increased Islamisation process in countries with Muslim majorities might be regarded in view of what Steve Bruce describes as the 'cultural defence' approach and 'cultural transition' either within a society or between societies. In the cultural defence approach Islamists moved 'Islam' into the political sphere. And as Bruce has noted, religion can

\footnotetext{
79 Ibn Hajar, Fath al-Bārī, 7: 732; hadīth no. 4252 [4425]. Author's translation in agreement with the editors.

${ }^{80}$ Fatima Mernissi, Women and Islam: An Historical and Theological Enquiry (Oxford: Basil Blackwell, 1987), 50-61.

81 Muḥammad al-Ghazālī,1989. al-Sunna al-nabawiyya bayna ahl al-ḥadìth wa-ahl al-ra y (Beirut: Dār al-Shurūq, 1989), 50.

82 At the end of my visit in August 2007, parliament was dissolved, due to an upcoming parliamentary election.
} 
flourish in cases when it has other tasks than to relate the individual to the supernatural. ${ }^{83}$ Moreover, Bruce has also noted that in times of frequent cultural transition an increased religiosity can occur as a countertrend to the secularisation process. In Muslim society, the increased modernisation and urbanisation of Muslim life and the migration of Muslims to countries with other religious and cultural traditions can represent such a cultural transition, which tends to impede the secularisation of society.

However, it might be that these countertrends to the secularisation process are only temporary impediments, rather than substantial obstructions that can block the secularisation process altogether. Weber's notion of rationality, an important factor for the secularisation process in the West is as well a substantial feature of the Muslim Brotherhood's ideology. The organisation's emphasis on science and technology is one aspect of this rationality, and its 'modern' approach to interpretations of the Islamic sources, which also encourages individualisation of interpretation, is another aspect.

Further, the Muslim Brotherhood's role in producing alternative understandings to that of the orthodox Islamic message in the shape of the Islamic law-school system, is an indication of the organisation's role in creating a diversity within the Islamic tradition, thus contributing to a weakening of religious commitments through a lack of a common accepted 'truth', and thus encouraging secularisation. Ödman points to how the liberal priests teaching common people to read the catechism opened up for a relativisation of faith that resulted in the individualisation and secularisation process in modern Swedish society. A similar trait is to be found within the Muslim Brotherhood's emphasis on Islamic education, which involves a heightening of religious knowledge among people in general.

Even the Islamist stress on the implementation of $\operatorname{Shari~}^{c} a$ in Muslim society might act as a catalyst of secularisation. Casanova observed how the link between the state and the church in Europe contributed to the differentiation between religious and secular institutions, leading to marginalisation and privatisation of religion in society. With the advent of feminism and human rights activism with the individual rights perspective in the Muslim world, the struggle for individual rights will necessarily also involve criticism of religious phenomena as a result of the state's involvement in religion. The three religious concepts, shürā, 'Islamic state', and 'female leadership' have all turned in a secular

${ }^{83}$ Bruce, God is Dead, 30. 
direction in the policy of the Muslim Brotherhood, as shürā has become 'western democracy', 'Islamic state' has become 'civil state', and 'Islamic leadership' has to a certain extent started to involve even women in the pattern of gender equality. This study anticipates a development towards a differentiation of religious and secular institutions in Jordan and a marginalisation of religion, as there is a tendency within the Muslim Brotherhood, the main public Islamist actor, to turn to secular concepts and ideas, leaving the traditional Islamic law-school ideas and the previous anti-western (thus anti-secular) concepts and understandings behind. As for the third proposition of secularisation; the decline of religious belief and practices, the material of this study can not give any indication of such a development at least at this stage of time. 